\title{
Paclobutrazol Applied on Cotyledonal Leaves and Quality of Cucumber, Squash, Melon and Watermelon Seedlings
}

\author{
Luz Llarely Cázarez Flores, Teresa de Jesús Velázquez Alcaraz, \\ Leopoldo Partida Ruvalcaba*, Tomás Díaz Valdés, Felipe Ayala Tafoya, \\ Norma Delia Zazueta Torres, Moisés Gilberto Yáñez Juárez
}

Faculty of Agronomy of the Autonomous, University of Sinaloa, Culiacan, Mexico

Email: *parpolo@yahoo.com.mx

How to cite this paper: Flores, L.Ll.C., de Jesús Velázquez Alcaraz, T., Ruvalcaba, L.P., Valdés, T.D., Tafoya, F.A., Torres, N.D.Z. and Juárez, M.G.Y. (2018) Paclobutrazol Applied on Cotyledonal Leaves and Quality of Cucumber, Squash, Melon and Watermelon Seedlings. Agricultural Sciences, 9, 264-271.

https://doi.org/10.4236/as.2018.93020

Received: January 29, 2018

Accepted: March 11, 2018

Published: March 14, 2018

Copyright $\odot 2018$ by authors and Scientific Research Publishing Inc. This work is licensed under the Creative Commons Attribution International License (CC BY 4.0).

http://creativecommons.org/licenses/by/4.0/

\begin{abstract}
The research was done to determine the effects of paclobutrazol (PBZ) through the dose of $150 \mathrm{mg} \cdot \mathrm{L}^{-1}$, on the quality of seedlings determined by the content of chlorophyll, height, leaf area, dry matter of roots and of the aerial part of cucumber, squash, melon and watermelon. Sowing of all species carried out on October 21, 2013 in polystyrene trays with 200 cavities filled with peat moss. Treatments were the doses of $150 \mathrm{mg}$ of $\mathrm{PBZ} \cdot \mathrm{L}^{-1}$ water and the control (distilled water). The solution with PBZ and the distilled water were applied only once with manual atomizer on cotyledonal leaves by mean of 25 shots made approximately with the same force, having put physical barriers between experimental units. In the four species (cucumber, squash, melon and watermelon) the PBZ increased the chlorophyll content in $26.0 \%, 14.9 \%$, $19.4 \%$ and $26.5 \%$, respectively, compared to the control; height decreased in $24.0 \%, 34.7 \%, 16.3 \%$ and $23.4 \%$; leaf area decreased in $40.1,0.5,30.4$ and $16.2 \%$; the dry matter of roots increased in $20.0 \%, 62.5 \%, 85.7 \%$ and $19.7 \%$; whereas in cucumber the dry matter of the aerial part increased $12.3 \%$, in squash decreased 5.3\%, and in melon and watermelon increased in the respective 22.9 and $3.3 \%$, so that the $150 \mathrm{mg}$ dose of $\mathrm{PBZ}$ can be used to produce seedlings with higher quality for transplant.
\end{abstract}

\section{Keywords}

Cucurbitaceae, Growth, Dose of Pbz, Dry Weight of Roots, Content of Chlorophyll

\section{Introduction}

Among the most cultivated cucurbits in Mexico are cucumber (Cucumis sativus 
L.), squash (Cucurbita pepo L.), melon (Cucumis melo L.) and watermelon [Citrullus lanatus (Thumb.) Matsum. \& Nakai]. With the first two species, in Sinaloa were sown 3442.8 and 3303.6 ha, respectively, during the Autumn-Winter and Spring-Summer periods of the agricultural cycle 2012-2013, in where the average yields respectively were obtained of 11.3 and $48.0 \mathrm{t} \cdot \mathrm{ha}^{-1}$; while with the last two species, during the same periods and the same cycle, 15 and 2784.5 ha, respectively, were planted to obtain the average yields respectively of 0 and 11.7 t.ha ${ }^{-1}[1]$.

Pallardy [2] reported that the use of growth regulators is an alternative means to modify shoot growth and biomass accumulation. The responses that produce in plants that receive growth regulators are diverse: there is alteration of compounds in the buds, redistribution of photosynthesis products destined to the growth of the cup towards defense compounds, growth of the radical system and storage of energy [3]. Actualy there are several technologies used as growth retardants, including paclobutrazol (PBZ), which is characterized by delaying cell division and elongation in tissues of the actively growing outbreak, without causing stem malformations or the leaves [4]. With said substance has been achieved to reduce shoot elongation, leaf expansion and stem diameter growth in many tree species [5], since it is an active inhibitor of gibberellic acid biosynthesis, retard the division and elongation cell, and consequently, growth in stem length of plants [6]. The retardant is absorbed passively through the leaves, stems and roots, and translocated by the xylem until the points of growth, where by inhibition of the action of gibberellin reduces cell division in the subapical part [7].

It has also been reported that between growth regulators is the paclobutrazol (PBZ), an inhibitor of gibberellins that is applied as solution to the soil where the roots of the trees are located, which once absorbed and translocated to the cup, this causes a reduction of the growth in length and diameter of new shoots [8]-[13].

With several research job, the effectiveness of PBZ to increase roots growth has been demonstrated [14]; increase the number, length and diameter of roots in cucumber, when the seeds are soaked in solution with $40 \mathrm{mg} \cdot \mathrm{L}^{-1}$ of $\mathrm{PBZ}$, but the hypocotyl length is reduced [15]. In seedlings of bell pepper and eggplant, the dose of $150 \mathrm{mg} \cdot \mathrm{L}^{-1}$ increased the fresh and dry matter of roots and dry matter of the aerial part [16].

In dose of $1.0 \mathrm{mg} \cdot \mathrm{L}^{-1}$ applied to the soil or $25 \mathrm{mg} \cdot \mathrm{L}^{-1}$ in foliar application, the PBZ has caused decrease in plant height, is it increase the stem diameter and roots development, improved the photosynthetic activity and the balance of water and with it the quality of plants for transplant, and is accelerate the formation and harvest of tomato fruits (Lycopersicon esculentum Mill.) cultivar "Precador", without leaving residues of PBZ in the fruits [17].

With the reduction in plant growth that cause the $\mathrm{PBZ}$, is increases the storage of carbohydrates (reserve substances of plants) and also is increases the production 
of chlorophyll and with this the of carbohydrates [18]. However, in the tree called white poplar (Populus alba L.), specie that in urban environments is use with ornamental purpose, the PBZ ( 0.4 and $0.8 \mathrm{~g}$ per plant with severe pruning), it significantly affected the growth of trunk, leaves and the ratio of total sugars/reducers, although the effect was lost in the next growth stage, perhaps because chlorophyll fluorescence $(\mathrm{Fv} / \mathrm{Fm})$ values were decreased, the PBZ did not improve plant vitality [19]. Contrary at this last, several authors have reported that PBZ increases the vitality of plants, understood this as the ability to tolerate stresses of biotic or abiotic origin [18] [20] [21]. In oil palm (Elaeis quineensis Jacq.), the PBZ increases leaf greenness and total chlorophyll content [22], equal that in maize and wheat [23].

In field production systems, the cucumber is managed in direct sowing, but in greenhouse conditions, to advance the harvest and take advantage of market windows, evade rodents and more efficiently use the high-cost hybrid seed, it is frecuent produce seedlings for transplant [24], which must be vigorous to ensure a good establishment and high production. The vigor is evaluated with the stem diameter, root growth, leaf area and dry matter in Solanum lycopersicon Mill. [24] [25]. For transplant are important the morphological measurements of seedlings, such as root length and height of seedlings, to ensure high presence of plants in the field or greenhouse [26].

The objective of the research was to determine the effects that produce the paclobutrazol through the $150 \mathrm{mg} \cdot \mathrm{L}^{-1}$ dose in the seedling quality, determined by the chlorophyll content, height, leaf area, dry matter of roots and of the aerial part of cucumber, squash, melon and watermelon.

\section{Materials and Methods}

The present study was carried out in the greenhouse of the Faculty of Agronomy of the Autonomous University of Sinaloa, Mexico, located between the geographical coordinates $24^{\circ} 37^{\prime} 29^{\prime \prime} \mathrm{LN}$ and $107^{\circ} 26^{\prime} 36^{\prime \prime} \mathrm{LO}, \mathrm{km} 17.5$ of the road Culiacan-Eldorado, during the period autumn-winter of the agricultural cycle 2013-2014, where was used cucumber of the cultivar "Alcázar", squash cultivar "Adelita", melon cultivar "Saturn" and watermelon of the cultivar "Jubilee", Sowing was done on October 21, 2013, in polystyrene trays with 200 cavities filled with peat moss (Sogemix-VTM, Quebec, Canada). Seedlings were irrigated with the necessary frequency, with $1.0 \mathrm{~g} \cdot \mathrm{L}^{-1}$ of $\mathrm{N}$, using urea as a source of nutrition.

The experimental design was randomized complete blocks with four replicates, where each experimental unit consisted of 100 plants (half tray) and the sample of 20 randomly selected plants. Treatments were the dose of 150 $\mathrm{mg} \cdot \mathrm{L}^{-1}$ of $\mathrm{PBZ}$ (that in other researches and species was the most appropriate in the effects caused) and distilled water (control). The dose of PBZ and distilled water were applied on October 30, 2013, only once through 25 shots with a hand spray on the cotyledonal leaves of the seedlings. Eight days after application (daa) of PBZ, the chlorophyll content was evaluated with a Spad-502 chlorophyll 
estimator (Minolta Co., Ltd. Japan), the evaluation was performed in the middle of 20 selected cotyledonal leaves random; the height was measured at 12 daa, from the base of the stem until the apical bud of the plant. The leaf area was evaluated in the first true leaf at $20 \mathrm{daa}$, and was calculated agree with the formula: leaf area $=($ length $\times$ width $) \times 0.851$ [27]. At 46 daa the roots and aerial part of the seedlings were dried in a stove at $72^{\circ} \mathrm{C}$ for $48 \mathrm{~h}$ until constant weight, to then determine the dry weight on a precision scale. Statistical analyzes were performed using the MINITAB statistical package 16, through analysis of variance and comparison of means with the Tukey test $(\mathrm{P} \leq 0.05)$.

\section{Results}

In the chlorophyll content of cucumber leaves significant differences were detected (Tukey, 0.05), such that in those plants treated with PBZ an increase of $26 \%$ was observed with respect to the control (Table 1), while height decreased in $24 \%$ and leaf area $40.1 \%$, compared to the respective control averages. In dry matter of the roots and aerial part, the PBZ was effective to induce greater accumulation, $20 \%$ more in roots and $12.3 \%$ more in the aerial part.

In squash (Table 2), the content of chlorophyll and dry matter of roots increased $14.9 \%$ and $62.5 \%$, respectively; the height decreased $34.7 \%$, but the leaf area and dry weight of the aerial part were statistically equal, with respect to the averages that were obtained in the control.

In Table 3 it can be observed that the chlorophyll content of the melon leaves had their greatest expression in the seedlings treated with PBZ, since in relation with the control increased 19.4\%; but the same seedlings had $16.3 \%$ less height and $30.4 \%$ less leaf area. However, the dry matter of roots it increased on $85.7 \%$, and although the dry matter of the aerial part was expressed without statistical differences, said biomass increased by $22.9 \%$, in comparation to the average of dry matter of the control seedlings.

In watermelon seedlings, the PBZ caused a $26.5 \%$ increase in the chlorophyll content in comparation with controls seedling (Table 4); also caused that the height and leaf area to decrease $23.4 \%$ and $16.2 \%$, respectively; however, the dry matter of the roots increased $19.7 \%$ and of the aerial part $3.3 \%$.

\section{Discussion}

The increase of leaf chlorophyll content in the four species (cucumber, squash, melon and watermelon), coincides with the reported by Percival and Albalushi

Table 1. Influence of paclobutrazol (PBZ) in the content of chlorophyll, height, leaf area and dry matter of roots and aerial part of cucumber seedlings.

\begin{tabular}{cccccc}
\hline Treatments & $\begin{array}{c}\text { Chlorophyll } \\
(\text { Spad units })\end{array}$ & $\begin{array}{c}\text { Height } \\
(\mathrm{cm})\end{array}$ & $\begin{array}{c}\text { Leaf area } \\
\left(\mathrm{cm}^{2}\right)\end{array}$ & $\begin{array}{c}\text { Dry matter } \\
\text { of roots }(\mathrm{g})\end{array}$ & $\begin{array}{c}\text { Dry matter } \\
\text { of aerial part }(\mathrm{g})\end{array}$ \\
\hline Control (water) & $33.1 \mathrm{~b}$ & $11.7 \mathrm{a}$ & $16.2 \mathrm{a}$ & $0.10 \mathrm{~b}$ & $0.57 \mathrm{~b}$ \\
PBZ $\left(150 \mathrm{mg} \cdot \mathrm{L}^{-1}\right)$ & $41.7 \mathrm{a}$ & $8.9 \mathrm{~b}$ & $9.7 \mathrm{~b}$ & $0.12 \mathrm{a}$ & $0.64 \mathrm{a}$ \\
\hline
\end{tabular}

Different letters in the same column indicate significant differences (Tukey, $\mathrm{P} \leq 0.05$ ). 
Table 2. Influence of the paclobutrazol (PBZ) in the content of chlorophyll, height, leaf area and dry matter of roots and aerial part of squash seedlings.

\begin{tabular}{cccccc}
\hline Treatments & $\begin{array}{c}\text { Chlorophyll } \\
\text { (Spad units) }\end{array}$ & $\begin{array}{c}\text { Height } \\
(\mathrm{cm})\end{array}$ & $\begin{array}{c}\text { Leaf area } \\
\left(\mathrm{cm}^{2}\right)\end{array}$ & $\begin{array}{c}\text { Dry matter } \\
\text { of roots }(\mathrm{g})\end{array}$ & $\begin{array}{c}\text { Dry matter } \\
\text { of aerial part }(\mathrm{g})\end{array}$ \\
\hline Control (water) & $43.0 \mathrm{~b}$ & $15.0 \mathrm{~b}$ & $16.7 \mathrm{a}$ & $0.08 \mathrm{~b}$ & $1.21 \mathrm{a}$ \\
PBZ $\left(150 \mathrm{mg} \cdot \mathrm{L}^{-1}\right)$ & $49.4 \mathrm{a}$ & $9.8 \mathrm{a}$ & $16.6 \mathrm{a}$ & $0.13 \mathrm{a}$ & $1.15 \mathrm{a}$ \\
\hline
\end{tabular}

Different letters in the same column indicate significant differences (Tukey, $\mathrm{P} \leq 0.05$ ).

Table 3. Influence of the paclobutrazol (PBZ) in the content of chlorophyll, height, leaf area, dry matter of roots and aerial part of melon seedlings.

\begin{tabular}{cccccc}
\hline Treatments & $\begin{array}{c}\text { Chlorophyll } \\
(\text { Spad units })\end{array}$ & $\begin{array}{c}\text { Height } \\
(\mathrm{cm})\end{array}$ & $\begin{array}{c}\text { Leaf area } \\
\left(\mathrm{cm}^{2}\right)\end{array}$ & $\begin{array}{c}\text { Dry matter } \\
\text { of roots }(\mathrm{g})\end{array}$ & $\begin{array}{c}\text { Dry matter of } \\
\text { aerial part }(\mathrm{g})\end{array}$ \\
\hline Control (water) & $32.0 \mathrm{~b}$ & $13.5 \mathrm{a}$ & $7.9 \mathrm{a}$ & $0.07 \mathrm{~b}$ & $0.61 \mathrm{a}$ \\
PBZ $\left(150 \mathrm{mg} \cdot \mathrm{L}^{-1}\right)$ & $38.2 \mathrm{a}$ & $11.3 \mathrm{~b}$ & $5.5 \mathrm{~b}$ & $0.13 \mathrm{a}$ & $0.75 \mathrm{a}$ \\
\hline
\end{tabular}

Means with different literal in the same column are statistically different (Tukey, $\mathrm{P} \leq 0.05$ ).

Table 4. Influence of the paclobutrazol (PBZ) in the content of chlorophyll, height, leaf area, dry matter of roots and aerial part of watermelon seedlings.

\begin{tabular}{cccccc}
\hline Treatments & $\begin{array}{c}\text { Chlorophyll } \\
(\text { Spad units })\end{array}$ & $\begin{array}{c}\text { Height } \\
(\mathrm{cm})\end{array}$ & $\begin{array}{c}\text { Leaf area } \\
\left(\mathrm{cm}^{2}\right)\end{array}$ & $\begin{array}{c}\text { Dry matter of } \\
\text { roots }(\mathrm{g})\end{array}$ & $\begin{array}{c}\text { Dry matter of } \\
\text { aerial part }(\mathrm{g})\end{array}$ \\
\hline Control (wate) & $27.9 \mathrm{~b}$ & $12.4 \mathrm{a}$ & $11.7 \mathrm{a}$ & $0.1525 \mathrm{~b}$ & $0.7525 \mathrm{a}$ \\
PBZ $\left(150 \mathrm{mg} \cdot \mathrm{L}^{-1}\right)$ & $35.3 \mathrm{a}$ & $9.5 \mathrm{~b}$ & $9.8 \mathrm{~b}$ & $0.1825 \mathrm{a}$ & $0.7775 \mathrm{a}$ \\
\hline
\end{tabular}

Means with different literal in the same column are statistically different (Tukey, $\mathrm{P} \leq 0.05$ ).

[18], since they also found more chlorophyll in plants treated with PBZ; is also related to what [17] reported in how much to that with the PBZ is induced improvement in the photosynthetic activity of tomato seedlings, since the increase the chlorophyll in the seedlings the photosynthetic process also increased; also have relation with the results of Partida et al. [23], since they observed more chlorophyll in plants of maize, wheat (cultivars "Río Colorado", "Baviacora" and "Romoga F-96"), and bell pepper cultivar. "Taranto" but disagrees with the results reported by Martínez et al. [19], since they observed decreased of values of chlorophyll fluorescence ( $\mathrm{Fv} / \mathrm{Fm})$.

The estimated decreases in seedling height coincide with the results of Keever et al. [8], Burch et al. [5], Singh [9], George and Nissen [10], Williams et al. [11], Bai et al. [12] and Grochowska et al. [13], since these authors have reported that the PBZ, once absorbed and translocated to the canopy of the plants, causes reduction of the growth in length of new shoots. Likewise, with the results published by Giovinazzo et al. [28], as these authors observed that PBZ reduced the size of tomatoes seedlings of the cultivars "Francyset", "Pavia" and "Montego" tomatoes by $45 \%$, of equal form with the of Velázquez et al. [29], who found that in tomato plants of the cultivar "Rio Grande" the PBZ retarded growth when foliarly applied at doses of 100,150 or $200 \mathrm{mg} \cdot \mathrm{L}^{-1}$ in plants of two 
to four true leaves. The results that Balamani and Poovaiah [30] obtained in potato also have relation with those of this investigation, since they reported that at using PBZ the height of plants decreased; likewise, with the results of Flores et al. [31], which they observed decreased height of potato plants, after applying $150 \mathrm{mg} \cdot \mathrm{L}^{-1}$ of PBZ, when the plants had 30 days old after the emergency.

The decreases of the leaf size here exposed coincide with those of Burch et al. [5], since they found that the PBZ, in addition to reducing shoot elongation, reduced leaf expansion in many tree species. The estimated results on dry matter of roots and of the aerial part have relation with those of Partida et al. [16], since in pepper seedlings they found that the PBZ at doses of 100,150 or $250 \mathrm{mg} \cdot \mathrm{L}^{-1}$ increased the length of the roots, with $100,150,200,250,300$ or $350 \mathrm{mg} \cdot \mathrm{L}^{-1}$ increased the dry matter of them, while the dry matter of the aerial part only increased with the dose of $150 \mathrm{mg} \cdot \mathrm{L}^{-1}$; in eggplant also they found that with 100 , 300 or $350 \mathrm{mg} \cdot \mathrm{L}^{-1}$, the PBZ increased the dry weight of roots and of the aerial part.

In the dry matter aspect of roots, the results also have relation wiht the of Watson [14], since this author refers that the PBZ increased the growth of roots; likewise, wiht the Berova and Zlatev [17], who observed that with $1.0 \mathrm{mg} \cdot \mathrm{L}^{-1}$ applied to the soil or with $25 \mathrm{mg} \cdot \mathrm{L}^{-1}$ in foliar application, the PBZ increased the development of roots in tomato seedlings. However, the results of this research differ from reported by Wood [32], through which is reported that the PBZ reduced the root growth in pecan trees [Carya illinoensis (Wangenh) C. Koch], which perhaps it was because of the difference in species and the dose applied.

As reported by Wien [24], these results can be used to advance harvest, take advantage of market windows, evade rodents and more efficient use of hybrid seed, when producing seedlings for transplant with the vigor that give plant height, stem diameter and the growth of roots, since according to Leskovar [26], the length of roots and height of seedlings allow to ensure high presence of plants in the field or greenhouse. sswWs

\section{Conclusion}

The dose of $150 \mathrm{mg} \cdot \mathrm{L}^{-1}$ of PBZ caused a decrease in height of cucumber, squash, melon and watermelon seedlings, and was effective to increase the chlorophyll content in its leaves and dry matter of roots; in only three of the species the leaf area decreased and the dry matter of the aerial part increased, since in squash did not diminish the leaf area and neither was it increased the dry matter of the aerial part, in such a form that the dose of $150 \mathrm{mg} \cdot \mathrm{L}^{-1}$ of $\mathrm{PBZ}$ can be used to apply in the cotyledonal leaf stage and produce seedlings with higher quality and probability of success for establishment in the production systems.

\section{References}

[1] SIAP (2013) Cierre de la producción agrícola por cultivo. https://www.gob.mx/siap/

[2] Pallardy, S.G. (2008) Physiology of Woody Plants. 3rd Edition, Academic Press, 
Cambridge, 464.

[3] Lilly, S.J. (2001) Arborists' Certification Study Guide. International Society of Arboriculture, Champaign, 222.

[4] Rojas, G.M. and Rovalo, M.M. (1985) Fisiología Vegetal Aplicada. McGraw-Hill, New York, 302.

[5] Burch, P.L., Wells, R.H. and Kline, W.N. (1996) Red Maple and Silver Maple Growth Evaluated 10 Years after Application of Paclobutrazol Tree Growth Regulator. Journal of Arboriculture, 22, 61-66.

[6] Tadao, A. Kin, M.Y., Nagata, N., Yamagishi, K., Takatsuto, S., Fujioka, S., Murofushi, N., Yamaguchi, I. and Yoshida, S. (2000) Characterization of Brassinazole, a Triazole-Type Brassinosteroid Biosynthesis Inhibitor. Plant Physiology, 123, 93-99. https://doi.org/10.1104/pp.123.1.93

[7] Early, J.D and Martín, G.C. (1988) Translocation and Breakdown of 14C-Labelled Paclobutrazol in Nemaguard Peach Seedlings. Hort Science, 23, 196-200.

[8] Keever, G.J., Foster, W.J. and Stephenson, J.C. (1990) Paclobutrazol Inhibits Growth of Woody Landscape Plants. Journal of Environmental Horticulture, 8, 41-47.

[9] Singh, Z. (2000) Effects of (2RS, 3RS) Paclobutrazol on Tree Vigour, Flowering, Fruit Set and Yield in Mango. Acta Horticulturae, 525, 459-462. https://doi.org/10.17660/ActaHortic.2000.525.67

[10] George, A.P. and Nissen, R.J. (2002) Control of Tree Size and Vigor in Custard Apple (Annona spp. Hybrid) cv. African Pride in Subtropical Australia. Australian Journal of Experimental Agriculture, 42, 503-512. https://doi.org/10.1071/EA01037

[11] Williams, D.R., Potts, B.M. and Smethurst, P.J. (2003) Promotion of Flowering in Eucalyptus nitens by Paclobutrazol Was Enhanced by Nitrogen Fertilizer. Canadian Journal of Forest Research, 33, 74-81. https://doi.org/10.1139/x02-157

[12] Bai, S., Chaney, W. and Qi, Y. (2004) Response of Cambial and Shoot Growth in Trees Treated with Paclobutrazol. Journal of Arboriculture, 30, 137-145.

[13] Grochowska, M.J., Hodun, M. and Mika, A. (2004) Improving Productivity of Four Fruit Species by Growth Regulators Applied Once in Ultra-Low Doses to the Collar. The Journal of Horticulture \& Science Biotechnology, 79, 252-259. https://doi.org/10.1080/14620316.2004.11511757

[14] Watson, G.W. (1996) Tree Root System Enchancement with Paclobutrazol. Journal of Arboriculture, 22, 211-217.

[15] Ali, A.R. (2009) Improving Germination Performance and Chilling Tolerance in Cucumber Seedlings with Paclobutrazol. International Journal of Vegetable Science, 15, 173-184. https://doi.org/10.1080/19315260802685768

[16] Partida, R.L., Velázquez, A.T.J., Díaz, V.T., Ayala, T.F. and Acosta, V.B. (2007) Paclobutrazol and Root and Shoot Growth in Bell Pepper and Eggplant Seedlings. Revista Fitotecnia Mexicana, 30, 145-150.

[17] Berova, M. and Zlatev, Z. (2000) Physiological Response and Yield of Paclobutrazol Treated Tomato Plants (Lycopersicon esculentum Mill.). Plant Growth Regulation, 30, 117-123. https://doi.org/10.1023/A:1006300326975

[18] Percival, G.C. and Albalushi, A.M.S. (2007) Paclobutrazol-Induced Drought Tolerance in Containerized English and Ever-Green Oak. Arboriculture \& Urban Forestry, 33, 397-409.

[19] Martínez, T.T., Plascencia, E.F.O. and Cetina, A.V.M. (2013) Growth and Vitality of 
Populus alba L. with Topping and Treated with Paclobutrazol. Revista Chapingo Serie Horticultura, 19, 381-388. https://doi.org/10.5154/r.rchsh.2013.05.016

[20] Navarro, A., Sánchez, B.M.J. and Bañon, S. (2007) Influence of Paclobutrazol on Water Consumption and Plant Performance of Arbutus unedo Seedlings. Scientia Horticulturae, 111, 133-139. https://doi.org/10.1016/j.scienta.2006.10.014

[21] Sharma, D.K., Dubey, A.K., Srivastav, M., Singh, A.K., Sairam, R.K., Pandey, R.N., Dahuja, A. and Kaur, C. (2011) Effect of Putrescine and Paclobutrazol on Growth, Physiochemical Parameters, and Nutrient Acquisition of Salt Sensitive Citrus Rootstock Karna khatta (Citrus karna Raf.) under $\mathrm{NaCl}$ Stress. Journal of Plant Growth Regulation, 30, 301-311. https://doi.org/10.1007/s00344-011-9192-1

[22] Nizam, K. and Te-chato, S. (2009) Optimizing of Root Induction in Oil Palm Plantlets for Acclimatizacion by Some Potent Plant Growth Regulators (PGRs). Journal of Agricultural Technology, 5, 371-383.

[23] Partida, R.L., Velázquez, A.T.J., Díaz, V.T., Ayala, T.F. and Acosta, V.B. (2012) Paclobutrazol para incrementar la producción de hortalizas y cereales. Académica Española, Saabrücken, $81 \mathrm{p}$.

[24] Wien, H.C. (1999) Trasplanting. In: Wien, H.C., Ed., The Physiology of Vegatble Crops, CABI Publishing, Department of Fruit and Vegetable Science, Cornel University, Ithaca, 37-68.

[25] Sánchez, del C.F., Ortiz, C.J., Mendoza, C.C., González, H.V. and Colinas, L.M.T. (1999) Morphological Traits Associated with a Tomato Ideotype for a Nonrestrictive Environment. Agrociencia, 33, 21-29.

[26] Leskovar, D.I. (2001) Producción y ecofisiología del trasplante hortícola. Texas A \& University, $24 \mathrm{p}$. http://www.uaaan.mx/postgrado/images/files/hort/simposio1/Curso.pdf

[27] Blanco, F. and Folegatti, M. (2003) A New Method for Estimating the Leaf Area Index of Cucumber and Tomato Plants. Horticultura Brasileira, 21, 666-669. https://doi.org/10.1590/S0102-05362003000400019

[28] Giovinazzo, R., Souza, M.V. and Hartz, T.K. (2001) Paclobutrazol Responses with Processing Tomato in France. Acta Horticulturae, 542, 355-358. https://doi.org/10.17660/ActaHortic.2001.542.46

[29] Velázquez, A.T.J., Partida, R.L., Acosta V.B. and Ayala T.F. (2008) Production of Tomato and Pepper Plant Applying Paclobutrazol on Foliage. Universidad $y$ Ciencia, 24, 21-28.

[30] Balamani, V. and Poovaiah, B.W. (1985) Retardation of Shoot Growth and Promotion of Tuber Growth of Potato Plants by Paclobutrazol. American Journal of Potato Research, 62, 363-369. https://doi.org/10.1007/BF02855607

[31] Flores, L.R., Sánchez, C.F., Rodríguez, P.J.E., Mora, A.R., Colinas, L.M.T. and Lozoya, S.H. (2011) Paclobutrazol, Uniconazole and Cycocel in Potato Seed-Tuber Production in Hydroponic Culture. Revista Chapingo Serie Horticultura, 17, 173-182. https://doi.org/10.5154/r.rchsh.2011.17.019

[32] Wood, B.W. (1988) Paclobutrazol Suppresses Vegetative Growth of Large Pecan Trees. HortScience, 23, 341-343. 